\title{
E-Module Development for Midwifery Care of Childbirth First Stage on Partograph Documentation System Success Improvement
}

\author{
Jusmawati \\ Department of Midwifery, Graduate School, Hasanuddin University, Indonesia \\ Corresponding author email: jusmaafria@gmail.com \\ Mardiana Ahmad \\ Department of Midwifery, Graduate School, Hasanuddin University, Indonesia \\ Email: mardiana908@gmail.com

\section{Prastawa Budi} \\ Departement of Chemistry, Hasanuddin University, Indonesia \\ Email: prastawa.budi@gmail.com \\ Hamdiah Ahmar \\ Midwifery Undergraduate Study Program, Mitra Bunda Health Institute, Batam, Indonesia \\ Email:hamdiah@mbp.ac.id
}

\begin{abstract}
Purpose: This study aims to determine the effect of the e-module of childbirth on the success of the partograph documentation system of midwifery DIII students using the Magguru application. Methods: This study uses a Quasi Experiment method. The number of samples was 90 people who were taken using total sampling technique. This design observation is carried out twice, namely before the treatment is carried out and according to the treatment. Data analysis used the Wilcoxon test to determine the effect of the e-module childbirth intervention on increasing learning success. Results: Based on the results of the study, the pretest scores were obtained in the demonstration/control group (10\%), e-module (23.3\%), e-module and demonstration (26.6\%), and post-test scores in the demonstration/control group. (10\%), e-module (100\%), e-module and demonstration (100\%). In the demonstration (control) group there was no increase in learning success, while in the e-module group and the emodule group with demonstrations there was an increase in learning success with a P-value of 0,000.Conclusion: Based on the research results, it can be concluded that the e-module (Magguru application) significantly improves the learning success of midwifery DIII students on partograph documentation knowledge.

Keywords---android, e-module, learning, partograph, student.
\end{abstract}

\section{Introduction}

In educational organizations currently looking for creative ways to solve the challenges associated with learning success that students face (Trichterborn et al., 2016), students' knowledge and skills in filling out partographs are still lacking, especially in pandemic conditions that require students to be able to. fill out partographs in distance learning. The development of the 4.0 Revolution-era made lecturers have to be able to develop methods and use of learning media that could increase student knowledge and skills in filling out partographs (Ratnaningsih, 2020; Prapitasari, 2020; Taheri et al., 2016).

In the learning process in the classroom to increase student activeness, this can be handled by applying a learning model, to support student success in the learning process in the classroom not necessarily determined by a good teacher or a steady curriculum, but also determined by the learning method used (Putra et al., 2017; Ahmar et al., 
2020). Learning in tertiary institutions tends to be one-way, namely the provision of material by lecturers so that the quality and learning outcomes are low. This learning makes students passive because they only listen to lectures so that their creativity is less developed (Ardian \& Munadi, 2015).

A good learning system must be able to influence the effectiveness of the learning process, the use of media in learning can generate desire, new interest, motivation, and stimulate learning activities. The development of technology makes many packaged learning media more attractive, one of which is in the form of applications (Wahyunita et al., 2020). Unsaturated and motivated too. One way to increase student learning motivation is the Learning method of learning (Abou El-Seoud et al., 2014). Skills are very important to be trained/developed because the skill process has a role to help students learn to develop their minds, thus providing space and opportunities to make discoveries, improve memory, and help students learn scientific concepts Arista \& Kuswanto (2018).

Prospective health workers, especially midwifery students, need to be prepared with skills and knowledge as early as possible to master and apply partographs. Midwifery students must be able to understand and understand about filling in partographs as knowledge material so that they can be competent to be applied during field practice. When filling in partographs, not only good knowledge is needed but more and more cases of labor and practice of filling in partographs really help students to fill in partographs correctly and correctly (Ariska, 2018).

The demonstration method is a method of presenting lessons by demonstrating and demonstrating to students about the material being taught. The demonstration method is used in learning the partograph filling material in the Asked II childbirth course. With a demonstration of the student acceptance process for lessons, the demonstration method is one of the methods widely used by lecturers to demonstrate practical learning with tools because it has a positive influence on learning achievement (Indah et al., 2018).

The absence of teaching materials in the form of modules can overcome problems in the learning process and elements of technology use. The presentation of the printed module can be transformed into electronic form, thus giving birth to the term e-module. With the absence of teaching materials in the form of android-based e-modules, the lecturers at midwifery DIII are very supportive and agree with the development of these teaching materials (Ginaya et al., 2018; Chen et al., 2020; Lin et al., 2003; Schnotz \& Bannert, 2003; Lewalter, 2003).

Midwifery is vocational education, so there are many skills that midwifery students must master. Students are expected to be skilled when they practice in a practice place (Hospital, Independent Practice Midwife, or Puskesmas). Midwifery care competencies in childbirth that must be mastered by a midwife are skills in doing/documenting partographs (Gans-Lartey et al., 2013; Bernitz et al., 2019; Fahdhy \& Chongsuvivatwong, 2005). Normal Childbirth Care (APN) relies heavily on the use of a pathography for early detection so that it can prevent and reduce morbidity and mortality in mothers and newborns. The partograph is a tool for monitoring the progress of the first stage of labor and information for clinical decisions (Anita, 2016).

The advantages of e-module development products that are developed provide new knowledge insights to students, e-learning modules make student learning more interesting and can make students learn more actively, can be used individually or in groups. One of the media that prioritizes the independence of students so that it makes emodules more practical and flexible to carry anywhere, because they do not require large space to carry and store them, and can be equipped with audio and video in one presentation package (Huwana, 2020).

\section{Methods}

This study used a Quasi Experiment with a non-equivalent control design for the design group. In this design the observations were made 2 times, namely before the treatment was carried out and after the treatment was carried out. In the intervention group and the control group, each pretest and postets were carried out. Sampling in this study was midwifery students in semester I II, totaling 90 respondents consisting of 30 (control) groups who were not given intervention, 30 e-module groups who were given intervention in the form of Magguru application learning media, and 30 e-module groups \& demonstrations given intervention in the form of mag guru applications and demonstration methods. Sampling in this study using total sampling. The instruments in this study consisted of an android-based e-module of childbirth, learning activity observation sheets, labor case questions that had been validated by a team of lecturers who taught the Asked II subject of labor, partograph sheets, partograph documentation checklists, student characteristics questionnaires, and respondent approval sheets (Susilawati et al.,2020). 
Result

Table 1

Characteristics of respondents

\begin{tabular}{|c|c|c|c|c|c|c|c|}
\hline \multirow{3}{*}{ Variable } & \multicolumn{7}{|c|}{ Group } \\
\hline & \multicolumn{2}{|c|}{ Demonstration } & \multicolumn{2}{|c|}{ E-module } & \multicolumn{2}{|c|}{$\begin{array}{c}\text { E-module \& } \\
\text { Demonstration }\end{array}$} & \multirow[t]{2}{*}{$P$-Value } \\
\hline & $\mathrm{N}$ & $\%$ & $\mathrm{n}$ & $\%$ & $\mathrm{n}$ & $\%$ & \\
\hline \multicolumn{8}{|l|}{ Age } \\
\hline$<19$ years old & 12 & 40 & 11 & 36,6 & 8 & 26,6 & \multirow{3}{*}{0,527} \\
\hline$\geq 19$ years old & 18 & 60 & 19 & 63,3 & 22 & 73,3 & \\
\hline Total & 30 & 100 & 30 & 100 & 30 & 100 & \\
\hline \multicolumn{8}{|l|}{ GPA } \\
\hline less $<3.00$ & 2 & 6,6 & 3 & 10 & 2 & 6,6 & \multirow{3}{*}{0,856} \\
\hline good $\geq 3.00$ & 28 & 93,3 & 27 & 90 & 28 & 93,3 & \\
\hline Total & 30 & 100 & 30 & 100 & 30 & 100 & \\
\hline \multicolumn{8}{|c|}{ Family Economic Level } \\
\hline <IDR. 2.000.000 & 4 & 13,3 & 5 & 16,6 & 5 & 16,6 & \multirow{3}{*}{0,787} \\
\hline$\geq$ IDR 2.000 .000 & 26 & 86,6 & 25 & 83,3 & 25 & 83,3 & \\
\hline Total & 30 & 100 & 30 & 100 & 30 & 100 & \\
\hline
\end{tabular}

Chi-square

Table 1. showed no significant differences between each group based on age, GPA, and family economic level. The table shows almost all respondents from the demonstration group $(40 \%)<19$ years old. While in the e-module intervention group $(36.6 \%)$, as well as e-modules and demonstrations $(26.6 \%)<19$ years old. GPA distribution in each group showed that almost all respondents had a good GPA of $93.3 \%$ in the demonstration group, $90 \%$ in the emodule group, and $93.3 \%$ in the e-module and demonstration groups. The distribution of family economic level in each group shows that almost all respondents have an income of more than IDR 2.000.000,-/month namely; 86.6\% in the demonstration group, $83.3 \%$ in the e-module group as well as in the e-module group, and $83.3 \%$ demonstration. So it is concluded that there is no significant influence on the success of learning between each age group, GPA, and family economic level.

Table 2

Differences in the success of stage i childbirth care learning partograph documentation in each control and intervention group

\begin{tabular}{|c|c|c|c|c|c|}
\hline \multirow[t]{2}{*}{ Group } & \multicolumn{2}{|c|}{ Successful } & \multicolumn{2}{|c|}{ Unsuccessful } & \multirow{2}{*}{$P$-value } \\
\hline & $\mathrm{N}$ & $\%$ & $\mathrm{~N}$ & $\%$ & \\
\hline \multicolumn{6}{|c|}{ Demonstration (Control) } \\
\hline Pretest $(n=30)$ & 3 & 10 & 27 & 90 & \multirow{2}{*}{0,115} \\
\hline Posttest $(n=30)$ & 3 & 10 & 27 & 90 & \\
\hline \multicolumn{6}{|l|}{ E-module } \\
\hline Pretest $(n=30)$ & 7 & 23,3 & 23 & 76,6 & \multirow[t]{2}{*}{0,000} \\
\hline $\operatorname{Posttest}(n=30)$ & 30 & 100 & 0 & 0 & \\
\hline \multicolumn{6}{|c|}{ E-module \& Demonstration } \\
\hline Pretest $(n=30)$ & 8 & 26,6 & 22 & 73,4 & \multirow[t]{2}{*}{0,000} \\
\hline Posttest $(n=30)$ & 30 & 100 & 0 & 0 & \\
\hline
\end{tabular}

Wilcoxon

Output Table 2. the pretest results show no significant difference in each group in filling partograph documentation. On the other hand, in the post-test results, there were significant differences in the e-module group and the e-module group and the demonstration in documenting partographs except for the control group there was still no significant difference. 
Table 2 shows that in the pretest results of the demonstration (control) group only a small proportion of students (10\%) succeeded in documenting the partograph and in the posttest it was obtained (10\%), which means that there was no difference in the success of filling in partograph documentation among midwifery DIII students. In the emodule group only $(23.3 \%)$ before the intervention was carried out students who succeeded in filling out partograph documentation of stage I labor care and increased after being given treatment in the form of labor teacher application to all respondents $(100 \%)$ succeeded in filling out partograph documentation. Whereas in the e-module and demonstration group before the intervention was carried out only (26.6\%) were successful and after giving treatment in the form of apprenticeship applications and learning demonstrations of success increased to all students (100\%) succeeded in documenting partographs of childbirth care during I. The above shows that there are differences in the success of filling in partograph documentation between the demonstration (control) group, the e-module group, the emodule group, and the demonstration group.

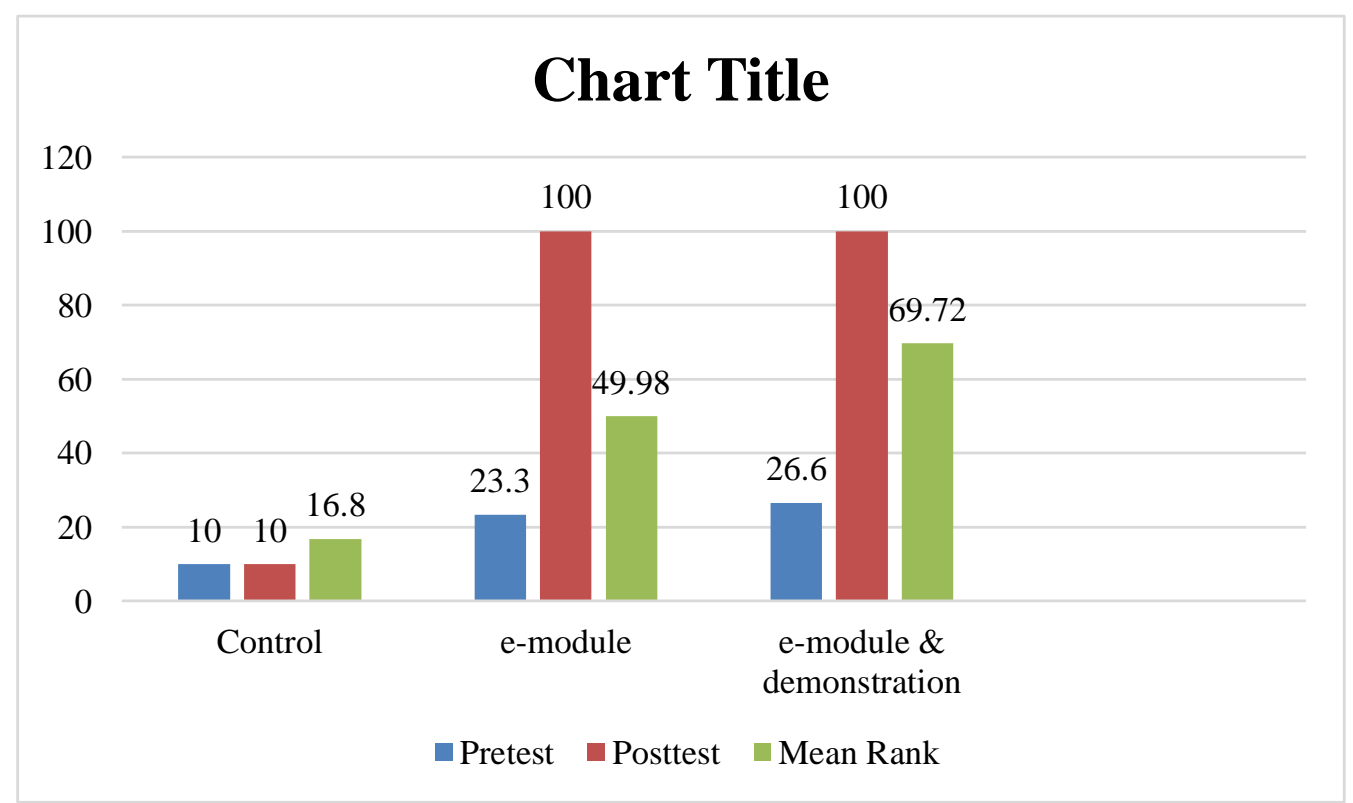

Figure 1. Percentage diagram for the improvement of learning success in partograph documentation before and after the intervention in each group

Figure 1 shows an increase in learning success in the demonstration (control), e-module, and e-module and demonstration groups, it can be seen in the diagram above the increase that occurred in each group. The increase in learning success shows that in the e-module group (76.6), the e-module and demonstration group was (73.4), while in the control group that was not given intervention in the form of e-module there was no increase in learning success, namely (27). So it can be concluded that the two groups had an increase in the success of filling in partograph documentation but there was a higher success increase in the e-module and demonstration groups with an effect of (69.72).

\section{Discussion}

The results of this study indicate that there is an increase in the success of student learning about partograph documentation which is significantly marked by a value $(p=0.000, p<0.05)$, thus the study assumes that e-modules and demonstration methods can be used to increase the success of filling in partograph documentation for students. This happens because students are given e-modules first to be able to study independently and during the demonstration learning process students can see the direct practice of filling in the partograph after the lecturer has finished demonstrating the partograph then it is the student's turn so that the learning process is more focused and well organized, the first meeting at student research is given material for stage I childbirth care with e-modules that have been studied after which the lecturer provides direct feedback to help students correct the mistakes made so that 
the e-module and the role of demonstrating $\mathrm{n}$ partograph are very influential in the partograph filling process $(\mathrm{Oh}, \mathrm{J}$ et al., 2019).

The increase in learning success in diagram 1, which shows that in the e-module group (76.6), the e-module and demonstration group was (73.4), while in the control group that was not given intervention in the form of e-module there was no increase in success. Learning namely (27). So it can be concluded that the two groups have an increase in the success of filling in partograph documentation but there is a higher success increase in the e-module and demonstration groups with an effect of (69.72). The increased success with learning using android-based e-modules is also shown in research in Wahyunita et al. (2020).

The learning media used greatly affects the effectiveness of the learning process, the use of media in learning can generate desire, new interest, motivation, and stimulate learning activities. Technological developments make many packaged learning media more attractive, one of which is in the form of an android-based e-module which can increase the knowledge of students/ midwives in documenting partographs for better first-stage labor (Anglano, 2014; Li et al., 2017; Karbab et al., 2018).

This assumption is supported by research Hairida et al. (2019), which states that the use of methods during learning has a major influence on the growth and development of creativity and learning interest of students towards Normal Childbirth Care (APN) relies heavily on the use of pathographs for early detection, a factor that influencing the success of teaching and learning, among others, can be from various aspects, both teachers, students, evaluation, teaching activities, teacher teaching styles, teacher approach styles, method use strategies, learning media and the atmosphere of the teaching and learning environment while the application of e-module itself can make it easier to apply, understand because of previous learning experiences (Aisy et al., 2020).

\section{Conclusion}

In the provision of android-based e-modules (mag guru) during the first stage of labor and demonstration methods, there was an increase in success compared to the (control) group, based on the results of e-module research with a higher combination of demonstration methods increasing the success of learning partograph documentation.

\section{Acknowledgments}

Our gratitude goes to all those who played a role in making this research. Thank you to the Director of Stikes Nani Hasanuddin Makassar and the Chair of the Midwifery DIII study program for providing permission and information so that this research can be researched properly and Thank you to all respondents who took the time to answer the research questionnaire so that the results in this study were obtained.

\section{References}

Abou El-Seoud, M., Taj-Eddin, I., Seddiek, N., El-Khouly, M., \& Nosseir, A. (2014). E-learning and students' motivation: A research study on the effect of e-learning on higher education. International journal of emerging technologies in learning (iJET), 9(4), 20-26.

Ahmar, H., Budi, P., Ahmad, M., Mustary, M., \& Hutagaol, I. O. (2020). The Influence of Problem Based Learning Model Based on Midwifery First Stage of Childbirth Care Module in Improving Learning Quality. International Journal of Psychosocial Rehabilitation, 24(2).

Aisy, D. R., Farida, F., \& Andriani, S. (2020). Pengembangan E-Modul Berbantuan Sigil Software Dengan Pendekatan Saitifik Pada Materi Sistem Persamaan Linier Dua Variabel (SPLDV). Edu Sains: Jurnal Pendidikan Sains dan Matematika, 8(1), 61-71.

Anglano, C. (2014). Forensic analysis of WhatsApp Messenger on Android smartphones. Digital Investigation, 11(3), 201-213. https://doi.org/10.1016/j.diin.2014.04.003

Anita, W. (2016). Metode Pembelajaran Dokumentasi Partograf Dalam Asuhan Kebidanan Pada Persalinan. Jurnal Endurance: Kajian Ilmiah Problema Kesehatan, 1(3), 136-143.

Ardian, A., \& Munadi, S. (2015). Pengaruh strategi pembelajaran student-centered learning dan kemampuan spasial terhadap kreativitas mahasiswa. Jurnal Pendidikan Teknologi dan Kejuruan, 22(4), 454-466.

Ariska, Y. (2018). Hubungan Pengetahuan Tentang Partograf Dengan Pelaksanaan Pengisian Partograf pada Mahasiswa D-III Kebidanan Di Yogyakarta. IJMS-Indonesian Journal on Medical Science, 5(2).

Arista, F. S., \& Kuswanto, H. (2018). Virtual Physics Laboratory Application Based on the Android Smartphone to Improve Learning Independence and Conceptual Understanding. International Journal of Instruction, 11(1), 1-16. 
Bernitz, S., Dalbye, R., Zhang, J., Eggebø, T. M., Frøslie, K. F., Olsen, I. C., ... \& Øian, P. (2019). The frequency of intrapartum caesarean section use with the WHO partograph versus Zhang's guideline in the Labour Progression Study (LaPS): a multicentre, cluster-randomised controlled trial. The Lancet, 393(10169), 340-348. https://doi.org/10.1016/S0140-6736(18)31991-3

Chen, B., Wang, Y., Xiao, L., Shen, Y., Qin, Q., Li, C., ... \& Sun, Z. (2020). Effects of mobile learning for nursing students in clinical education: a meta-analysis. Nurse Education Today, 104706. https://doi.org/10.1016/j.nedt.2020.104706

Fahdhy, M., \& Chongsuvivatwong, V. (2005). Evaluation of World Health Organization partograph implementation by midwives for maternity home birth in Medan, Indonesia. Midwifery, 21(4), 301-310. https://doi.org/10.1016/j.midw.2004.12.010

Gans-Lartey, F., O'Brien, B. A., Gyekye, F. O., \& Schopflocher, D. (2013). The relationship between the use of the partograph and birth outcomes at Korle-Bu teaching hospital. Midwifery, 29(5), 461-467. https://doi.org/10.1016/j.midw.2012.03.002

Ginaya, G., Rejeki, I. N. M., \& Astuti, N. N. S. (2018). The effects of blended learning to students' speaking ability. International journal of linguistics, literature and culture, 4(3), 1-14.

Hairida, H., Arifiyanti, F., Safrilianti, V., Erwinda, D., Apriliani, S., \& Ahmadiyah, A. (2019). the Local Wisdom of Kubu Raya Society and the Implementation in Science Learning. Journal of Education, Teaching and Learning, 4(2), 281-286.

Huwana, E. (2020). Pengembangan E-Modul Pembelajaran Matematika Berbasis Pendekatan Kontekstual Pada Siswa Kelas Vii SMP Negeri 5 Salatiga, Kecamatan Sidomukti, Kota Salatiga, Tahun Pelajaran 2020/2021.

Indah, O. D., Crestiani, J., \& Ramadhana, M. A. (2018). Nonverbal Communication Used by Students of Informatics Study Program in Studying English through Lesson Study. Jurnal Studi Guru dan Pembelajaran, 1(1), 42-48.

Karbab, E. B., Debbabi, M., Derhab, A., \& Mouheb, D. (2018). MalDozer: Automatic framework for android malware detection using deep learning. Digital Investigation, 24, S48-S59. https://doi.org/10.1016/j.diin.2018.01.007

Lewalter, D. (2003). Cognitive strategies for learning from static and dynamic visuals. Learning and Instruction, 13(2), 177-189. https://doi.org/10.1016/S0959-4752(02)00019-1

Li, L., Bissyandé, T. F., Papadakis, M., Rasthofer, S., Bartel, A., Octeau, D., ... \& Traon, L. (2017). Static analysis of android apps: A systematic literature review. Information and Software Technology, 88, 67-95. https://doi.org/10.1016/j.infsof.2017.04.001

Lin, Y. G., McKeachie, W. J., \& Kim, Y. C. (2003). College student intrinsic and/or extrinsic motivation and learning. Learning and individual differences, 13(3), 251-258. https://doi.org/10.1016/S1041-6080(02)00092-4

Oh, J., Kim, S. J., Kim, S., Kang, K. A., Kan, J., \& Bartlett, R. (2019). Development and evaluation of flipped learning using film clips within a nursing informatics course. Japan Journal of Nursing Science, 16(4), 385-395.

Prapitasari, R. (2020). Pembelajaran Daring Partograf Pada Mata Kuliah Asuhan Kebidanan Persalinan Masa Pandemi. Jurnal Ekonomi, Sosial \& Humaniora, 2(02), 123-128.

Putra, K. W. B., Wirawan, I. M. A., \& Pradnyana, G. A. (2017). Pengembangan e-modul berbasis model pembelajaran discovery learning pada mata pelajaran "sistem komputer" untuk siswa kelas x multimedia smk negeri 3 singaraja. Jurnal Pendidikan Teknologi dan Kejuruan, 14(1).

Ratnaningsih, S. (2020). The Importance of Environmental Education as a STEM Education in the Field of Science for Elementary School Students to Anticipate Natural Disasters in Indonesia.

Schnotz, W., \& Bannert, M. (2003). Construction and interference in learning from multiple representation. Learning and instruction, 13(2), 141-156. https://doi.org/10.1016/S0959-4752(02)00017-8

Susilawati, S., Pramusinta, P., \& Saptaningrum, E. (2020). Penguasaan Konsep Siswa Melalui Sumber Belajar eModul Gerak Lurus dengan Software Flipbook Maker. UPEJ Unnes Physics Education Journal, 9(1), 36-43.

Taheri, M., Unterholzer, T., Hölzle, K., \& Meinel, C. (2016, March). An educational perspective on design thinking learning outcomes. In ISPIM Innovation Symposium (p. 1). The International Society for Professional Innovation Management (ISPIM).

Trichterborn, A., Zu Knyphausen-Aufseß, D., \& Schweizer, L. (2016). How to improve acquisition performance: The role of a dedicated M\&A function, M\&A learning process, and M\&A capability. Strategic Management Journal, 37(4), 763-773.

Wahyunita, V. D., Suzana, V., \& Munadhiroh, M. (2020). Penerapan Media Pembelajaran Video Berbasis Web Sebagai Sumber Belajar Pengisian Partograf. Quality: Jurnal Kesehatan, 14(1), 11-18. 